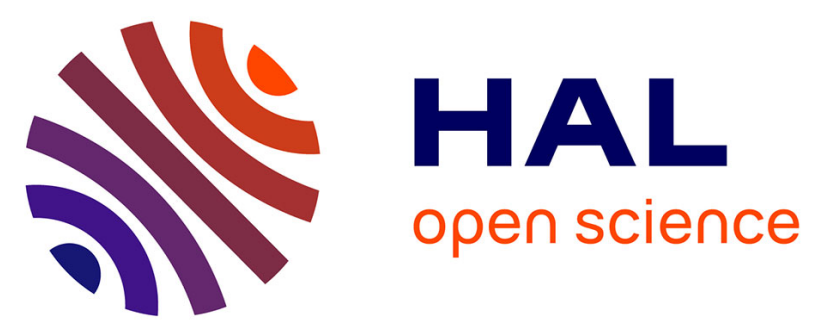

\title{
Exploring the potential of brown bear (Ursus arctos arctos) as a long-distance seed disperser: a pilot study in South-Western Europe
}

\author{
A. Lalleroni, P.Y. Quenette, Simon Boudsocq, M. Pellerin, Christophe
}

Baltzinger

\section{To cite this version:}

A. Lalleroni, P.Y. Quenette, Simon Boudsocq, M. Pellerin, Christophe Baltzinger. Exploring the potential of brown bear (Ursus arctos arctos) as a long-distance seed disperser: a pilot study in SouthWestern Europe. Mammalia, 2017, 81 (1), pp.1-9. 10.1515/mammalia-2015-0092 . hal-02605426

\section{HAL Id: hal-02605426 \\ https://hal.inrae.fr/hal-02605426}

Submitted on 26 May 2020

HAL is a multi-disciplinary open access archive for the deposit and dissemination of scientific research documents, whether they are published or not. The documents may come from teaching and research institutions in France or abroad, or from public or private research centers.
L'archive ouverte pluridisciplinaire HAL, est destinée au dépôt et à la diffusion de documents scientifiques de niveau recherche, publiés ou non, émanant des établissements d'enseignement et de recherche français ou étrangers, des laboratoires publics ou privés.

\section{(ㅇ)(1) $\$$}

Distributed under a Creative Commons Attribution - NonCommercial - NoDerivatives| 4.0 


\section{Exploring the potential of brown bear (Ursus arctos arctos) as a long-distance seed disperser: a pilot study in South-Western Europe}

DOI 10.1515/mammalia-2015-0092

Received June 3, 2015; accepted January 12, 2016

\begin{abstract}
Plant dispersal is crucial to maintaining plant community dynamics, especially in the current context of rapid environmental changes such as global warming and landscape fragmentation. We seized the opportunity to carry out a pilot study on endozoochorous dispersal by the endangered Pyrenean brown bear. We based our study on faeces collected by the Brown Bear Network and location data from three bears fitted with GPS collars and translocated from Slovenia to the Pyrenees in 2006. We studied 39 faecal samples, 25 of which contained seeds from two to three different taxa. We identified a total of 47 plant taxa, 30 to the genus level and 21 to the species level. The seeds from plants bearing fleshy fruits: Vaccinium myrtillus or uliginosum, Rubus idaeus, Malus sylvestris and Sorbus sp., but also dry fruits: Thymus sp., Betula pendula or alba, were the most frequently recovered. We estimated average distances moved by bears to vary from 0.85 to $1.34 \mathrm{~km}$ over a 6-h period, corresponding to the median gut retention time, $\mathrm{GRT}_{50 \%}$ for their berry-based diet in summer and fall. Bears may thus promote the long-distance dispersal of fleshy forest fruits, over longer
\end{abstract}

*Corresponding author: Christophe Baltzinger, UR EFNO, Centre de Nogent-sur-Vernisson, Irstea, F-45290 Nogent-sur-Vernisson, France, e-mail: christophe.baltzinger@irstea.fr.

http://orcid.org/0000-0003-2980-6238

Aurélie Lalleroni: UR EFNO, Centre de Nogent-sur-Vernisson, Irstea, F-45290 Nogent-sur-Vernisson, France; and ONCFS, Unité Prédateurs Animaux Déprédateurs, Equipe Ours, F-31800 Villeneuve de Rivière, France

Pierre-Yves Quenette: ONCFS, Unité Prédateurs Animaux Déprédateurs, Equipe Ours, F-31800 Villeneuve de Rivière, France Tanguy Daufresne: Inra, UMR 210 Eco\&Sols, F-34060 Montpellier, France

Maryline Pellerin: ONCFS, Unité Cervidés-Sanglier, F-38610 Gières, France distances than other sympatric mammals, involved in the dispersal of plants from open areas.

Keywords: endozoochory; gut retention time; plantanimal interactions; seed dispersal; telemetry; Ursus arctos arctos.

\section{Introduction}

In the context of global warming and habitat fragmentation, plant dispersal is becoming an increasingly more important aspect of plant community dynamics and may be a key process for maintaining plant diversity. According to Cain et al. (1998), the current distribution of some plant species may even rely on rare (one seed in a thousand), long-distance (more than $1 \mathrm{~km}$ ) dispersal events.

Worldwide the decrease in or the extinction of longdistance dispersers like large mammals due to overhunting and habitat destruction may have a significant local impact on plant dispersal rates, with potential implications for the conservation of rare species (Boulanger et al. 2011).

Large omnivorous mammals such as wild boars and bears may have a particular impact on long-distance dispersal in a changing environment (Willson and Gende 2004, Picard and Baltzinger 2012). Indeed, omnivores have opportunistic, variable seasonal diets (Koike et al. 2008, Koike et al. 2012) and can travel long distances across diverse habitats (Clevenger et al. 1990, Huber and Roth 1993, Quenette et al. 2001, Dahle and Swenson 2003).

In Southern Europe, brown bear (Ursus arctos arctos L. 1758) populations are scarce and isolated. Several countries are currently undertaking significant efforts to protect and reinforce local populations that have been on the verge of extinction (Taberlet et al. 1997, Wiegand et al. 1998, Mustoni et al. 2003, Preatoni et al. 2005, 
Mateo-Sanchez et al. 2014). To aid these population recovery efforts, a better understanding of the ecological role of the brown bear and its impact on local biodiversity is crucial. As an example, how bears may affect the genetic structure of the plants in their habitat through seed consumption and dispersal is still poorly documented, but see Elfström et al. (2013) for U. arctos arctos in Europe; Patten (1993), Willson and Gende (2004) for Ursus arctos horribilis in North America; and also Auger et al. (2002), Kuhn and Wall (2007) for Ursus americanus.

In this note, we present our preliminary results on endozoochorous seed dispersal by a relict brown bear population in the Pyrenees mountains (Southern France/ Northern Spanish border, see Figure 1). This population is being monitored by the Bear Program of the National Hunting and Wildlife Agency (Office National de la Chasse et de la Faune Sauvage). We addressed the following three questions:

Q1 - Can we document endozoochorous seed dispersal by brown bears in the Pyrenees mountains? And if so:
Q2 - Are the plants and seeds moved by bears representative of the species pool present in the local habitat or do bears select some specific taxa?

Q3 - How far may brown bears disperse seeds in our study area?

\section{Materials and methods}

\section{Pyrenean brown bear population}

The brown bear population in the Pyrenees mountains decreased regularly throughout the 20th century: 150200 bears were present in the area at the beginning of 20th century, about 70 bears after the Second World War (Couturier 1954) and finally, only five or six individuals in the western Pyrenees in 1995 with a range totalling about $1000 \mathrm{~km}^{2}$ on both sides of the French/Spanish border (Taberlet et al. 1997). In 1993, the European LIFE projects initiated brown bear recovery plans based on

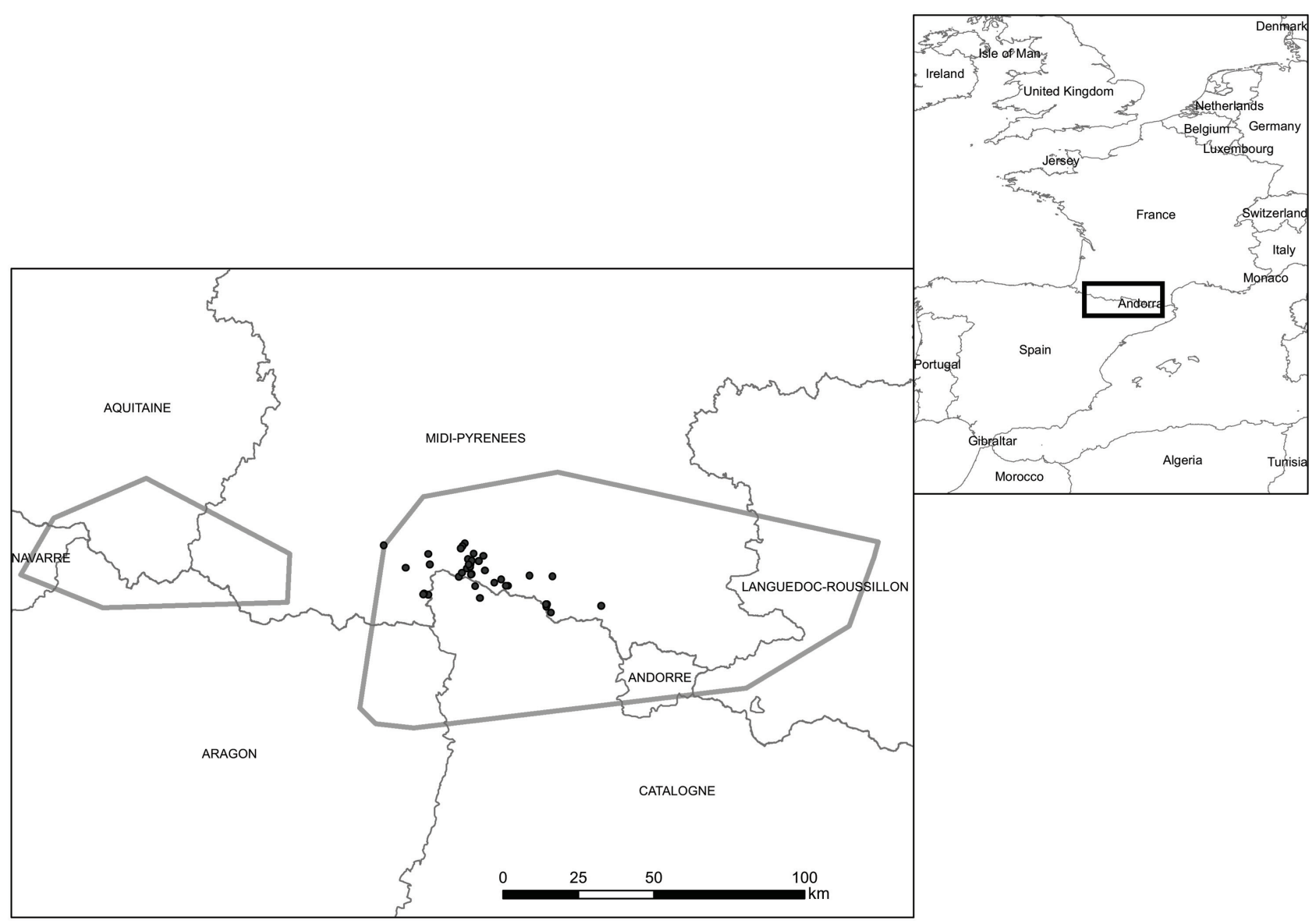

Figure 1: Western and central core brown bear subpopulations in the Pyrenees mountains from 2008 to 2012 and locations (full grey circles) of faeces used in our pilot study and collected by the Brown Bear Network. 
reintroductions from Slovenia into the western and central Pyrenees. However, for political reasons, bears were only reintroduced in the central Pyrenees. Two adult females and one male were released in 1996-1997, then another four adult females and one male in 2006 (Quenette et al. 2001, Quenette et al. 2006). After these reintroductions, the population grew and at least 22 individuals were detected in 2012 in two core subpopulations (western and central). These subpopulations are isolated regarding female exchange (Camarra et al. 2014). The western subpopulation has been composed of only two males since 2004 and will certainly disappear if no females are translocated or if they cannot reach the western subpopulation by natural migration.

\section{Study area}

The study was conducted in the central Pyrenees mountains, which cover $2000-2500 \mathrm{~km}^{2}$ on both the French and Spanish sides of the border. Elevations range from 500 to $3400 \mathrm{~m}$. More than $40 \%$ of the area is forested between 800 and $1600 \mathrm{~m}$ with pure or mixed stands of beech (Fagus sylvatica) and silver fir (Abies alba). At higher elevations, other deciduous tree species include oak (Quercus spp.), chestnut (Castanea sativa), hazel (Corylus avellana) and common birch (Betula alba). Pasturelands, rhododendron (Rhododendron ferrugineum), heather (Calluna vulgaris) and bilberry (Vaccinium Myrtillus) dominate above $1800 \mathrm{~m}$.

\section{Faeces}

Each faeces sample was collected in situ via two main monitoring types: first, through systematic monitoring on predefined study areas and following established protocols (using pedestrian surveys, checking station controls and GPS relocations); then, through opportunistic detection by hikers, hunters, shepherds and members of the Brown Bear Network. Each faeces sample is then validated by the Brown Bear Network.

From a total of 156 faeces samples available and stored for conservation in a freezer, we kept 39 brown bear faeces collected in the Pyrenees from May 1998 to February 2013. Our pool of faeces samples covered the whole active period for brown bears in the Pyrenees (from February until November), with two to four samples per month. In order to be sure that our faeces samples all came from independent defecation events, we screened the samples according to precise detection locality (latitude, longitude), collection date and individual genetical assignment. As much as possible, we selected samples assigned to one of the three GPS-collared bears (Balou, Hvala and Sarousse) introduced from Slovenia in 2006 to reinforce the population, thus corresponding to almost half of our samples (19 faeces). We analysed $5 \mathrm{~g}$ of dried matter from each faeces sample. The dried matter was sieved through four different grid sizes $(5 \mathrm{~mm}, 1.5 \mathrm{~mm}, 800 \mu \mathrm{m}$ and $100 \mu \mathrm{m})$ and all the contents were sorted. We identified six types of macro-elements: hair, ants, bone fragments, honey, plant fragments and seeds. We identified the seeds following the Digital Seed Atlas of the Netherlands (Cappers et al. 2006), the Illustrated Flora of the Pyrenees (Saule 1991) and the reference collections of the National Museum of National History in Paris. We compared the list of species obtained with the list of species inventoried in the study area during botanical surveys and compiled by the National Botanical Conservatory from the Pyrenees and Midi-Pyrenees (CBNPMP, http://cbnpmp.blogspot.fr/).

\section{Plant and seed traits}

To address whether bears randomly disperse species or whether a selective dispersal filter based on plant traits (Q2) is at play, we classified the seeds identified in the faeces and the plants present in the bear habitat according to four ecological characteristics:

- Main dispersal mode: We retained the eight main strategies usually taken into consideration (Howe and Smallwood 1982, Kleyer et al. 2008), four abiotic vectors (anemochory, autochory, barochory and hydrochory) and four biotic vectors (dyszoochory, endozoochory, epizoochory and myrmecochory).

- Fruit type: We distinguished fleshy fruits from dry fruits.

- Main habitat: We embedded four types (forests; forest edges and clearings; open areas; and wet habitats including bogs and sedge and reed areas).

- Light requirement: We extracted from plant traits database (Julve 1998) the L-Ellenberg index ranging from one for sciaphilous species to nine for light-demanding species (Ellenberg et al. 1991), and we further classified plants into two groups: mostly sciaphilous to intermediary species $(1 \leq \mathrm{L} \leq 5)$ as opposed to more light-demanding species $(6 \leq \mathrm{L} \leq 9)$.

\section{Dispersal distance}

To estimate dispersal distance, we used the location data for the three bears introduced from Slovenia in 2006 to 
Table 1: Description of the GPS data (tracking period, number and quality of scheduled $3 \mathrm{~h}$ locations) for each bear monitored.

\begin{tabular}{lrrr}
\hline Bear individuals & GPS tracking period & $\begin{array}{r}\text { Total number of scheduled 3 h } \\
\text { locations obtained }\end{array}$ & $\begin{array}{r}\text { Number (\%) of locations } \\
\text { with PDOP } \mathbf{1 0}\end{array}$ \\
\hline Hvala + & $01 / 07 / 2006-03 / 07 / 2007$ & 858 & $742(86 \%)$ \\
Sarousse + & $07 / 11 / 2006-03 / 12 / 2007$ & 1124 & $956(85 \%)$ \\
Balou 0 & $11 / 07 / 2006-16 / 06 / 2007$ & 1037 & $899(87 \%)$ \\
\hline
\end{tabular}

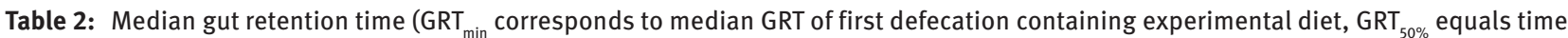

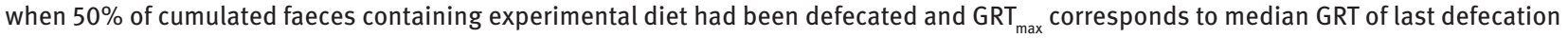
containing experimental diet, in hours:minutes) and median number of defecations per day, experimentally assessed for two diet types (berry-based and carcass-based) on six captive brown bears (see Elfström et al. 2013).

\begin{tabular}{lrrrr}
\hline & GRT $_{\text {min }}$ (hours:minutes) & GRT $_{\text {50\% }}$ (hours:minutes) & GRT $_{\text {max }}$ (hours:minutes) & Defecations/day \\
\hline Berry-based diet & $3: 05$ & $5: 47$ & $15: 27$ & 7.1 \\
Carcass-based diet & $8: 02$ & $14: 30$ & $16: 16$ & 4.0 \\
\hline
\end{tabular}

reinforce the Pyrenean population (Table 1). Each bear had been (i.e. at the time of introduction) fitted with a GPS/GSM 4000L radio-collar (Lotek Wireless, Fish and Wildlife Monitoring, Newmarket, Ontario, Canada) to provide a scheduled location every $3 \mathrm{~h}$. We kept only the locations with a position dilution of precision, $\mathrm{PDOP} \leq 10$. For a given season, we chose a location and for each subsequent location, recorded the straight-line distance from the chosen location and the time elapsed. We then calculated the average and maximal distances covered by each bear in spring (post-hibernation), summer and fall (pre-hibernation over-eating) over the cumulative 3-h time slots, following Westcott et al. (2005). All locations were considered to be similar to one another, as we had no information related to the feeding phases of the animals.

We used the median gut retention time ( $\mathrm{GRT}_{\text {min }}, \mathrm{GRT}_{50 \%}$ and $\mathrm{GRT}_{\max }$ ) experimental assessments from Elfström et al. (2013), who measured GRT on captive brown bears fed two contrasted seasonal diets, namely, carcasses or berries (Table 2). We then coupled the distances covered by our three selected individuals with the corresponding median GRT to assess potential seed dispersal distances (Koike et al. 2011).

\section{Statistical analysis}

To assess if and how brown bears act as a filter of the local flora through endozoochorous seed dispersal for each plant trait studied, we compared the proportion of plants whose seeds had been found in bear faeces (observed value) with the proportion of plants present in the bear habitat (expected value), for each plant trait category, using $\chi^{2}$. We kept a threshold $\mathrm{p}$-value $=0.05$ for significance. Hence, a non-significant test implies that bears disperse plant species according to their availability in the local flora.

\section{Results}

\section{Q1 - Brown bear disperse seeds by endozoochory}

Each analysed faecal sample contained from one to five types $(n=4)$ of macro-elements. Plant fragments and seeds were the most frequent types all year round and were, respectively, found in 25 and 31 samples out of a total of 39 samples (Table 3). The other macro-element types are given in decreasing order: ants $(\mathrm{n}=14)$, hairs $(\mathrm{n}=12)$, honey $(n=4)$ and the least representative were bone fragments (found in only two samples). Seeds were mostly present in summer, fall and winter with a peak in fall, and were rather rare in spring. Ants were more frequent in summer whereas hairs were mostly found in spring.

Table 3: Frequency of the different dietary items detected in bear faeces by season ( $n=$ number of faeces samples/season) and the all year.

Plant fragments Seeds Ants Hairs Honey Bones (no seeds)

\begin{tabular}{|c|c|c|c|c|c|}
\hline Spring $(n=13)$ & $77 \%$ & $38 \% \quad 38 \%$ & $31 \%$ & $8 \%$ & $8 \%$ \\
\hline Summer $(n=12)$ & $83 \%$ & $67 \% \quad 58 \%$ & $25 \%$ & $8 \%$ & $8 \%$ \\
\hline Fall $(n=8)$ & $63 \%$ & $88 \% \quad 25 \%$ & $25 \%$ & $25 \%$ & $0 \%$ \\
\hline Winter $(n=6)$ & $100 \%$ & $83 \% \quad 0 \%$ & $50 \%$ & $0 \%$ & $0 \%$ \\
\hline All year $(n=39)$ & $79 \%$ & $64 \% 36 \%$ & $31 \%$ & $10 \%$ & $5 \%$ \\
\hline
\end{tabular}

The most frequent item found for a given season is indicated in bold. 
We sorted out 47 types of seeds, of which 30 were identified to the genus level and 21 to the species level (Table 4), resulting in 16 families and 25 genera. The faecal samples contained on average two to three taxa, but one sample contained eight different taxa.

\section{Q2 - Characteristics of the taxa dispersed and comparison with the taxa present in bear habitat}

Seeds from the fleshy fruits of Vaccinium myrtillus or uliginosum, Rubus idaeus, Malus sylvestris and Sorbus sp. but also those from the dry fruits of Thymus sp. and Betula pendula or alba were the most frequently encountered species (Table 4). Among the 30 taxa dispersed and identified, we found 20 grasses or forbs, five shrubs and five trees. Most of the seeds belonged to dry fruits $(n=23$ vs. $\mathrm{n}=7$ for fleshy ones), but when present in a sample, the seeds from fleshy fruits were much more numerous. A majority of species were light demanding with L-Ellenberg index values between six and nine for 22 taxa. The 30 taxa originated from open habitats $(n=11)$, edges/clearings $(n=6)$, forests $(n=9)$ and wet habitats $(n=4)$. Among them, seven main dispersal strategies were represented: anemochory, autochory, barochory, hydrochory, dyszoochory, endozoochory and epizoochory. Epizoochorous $(n=11)$ and endozoochorous $(n=11)$ taxa were the most numerous.

When we compared the flora dispersed to the flora available in the bear habitat, we found that bear were most likely to disperse endozoochorous and dyszoochorous $\operatorname{taxa}\left(\chi_{(7)}^{2}=63.34, \mathrm{p}<0.0001\right)$, and taxa from forest habitats rather than other habitats $\left(\chi_{(3)}^{2}=14.52, p=0.002\right)$. We found

Table 4: List of the seeds identified in the 39 faecal samples studied in order by family, genus and species when possible.

\begin{tabular}{|c|c|c|c|c|c|c|}
\hline Family & Genus & Species & French common name & District & Study area & MNHN \\
\hline Amaryllidaceae & Allium & sphaerocephalon & Ail à tête ronde & $1 / 1$ & $X$ & $X$ \\
\hline Aquifoliaceae & Ilex & aquifolium & Houx & $1 / 1$ & $x$ & \\
\hline Betulaceae & Betula & pendula or alba & Bouleau & $1 / 3$ & $\mathrm{X}$ & $\mathrm{X}$ \\
\hline Betulaceae & Betula & pendula & Bouleau verruqueux & $2 / 2$ & $X$ & $X$ \\
\hline Ericaceae & Vaccinium & uliginosum or myrtillus & Airelle & $4 / 4$ & $X$ & $X$ \\
\hline Ericaceae & Vaccinium & myrtillus & Myrtille & $4 / 4$ & $X$ & $X$ \\
\hline Fagaceae & Quercus & humilis & Chêne pubescent & $1 / 1$ & $X$ & $X$ \\
\hline Fagaceae & Fagus & sylvatica & Hêtre & $1 / 1$ & $X$ & $X$ \\
\hline Fabaceae & Lotus & corniculalus & Lotier corniculé & $1 / 1$ & $X$ & \\
\hline Fabaceae & Lotus & pedunculatus & Lotier des marais & $1 / 1$ & $X$ & \\
\hline Juncaceae & Juncus & effusus & Jonc diffus & $1 / 1$ & $\mathrm{X}$ & $\mathrm{X}$ \\
\hline Lamiaceae & Thymus & pulegioides & Thym de bergère & $3 / 3$ & $X$ & \\
\hline Lamiaceae & Thymus & sp. & Thym & $4 / 5$ & $X$ & \\
\hline Lamiaceae & Teucrium & chamaedrys & Germandrée petit-chêne & $1 / 1$ & $\mathrm{X}$ & \\
\hline Onagraceae & Epilobium & montanum & Épilobe des montagnes & $1 / 1$ & $X$ & \\
\hline Oxalidaceae & Oxalis & acetosella & Oxalis petite oseille & $1 / 1$ & $X$ & $X$ \\
\hline Plantaginaceae & Plantago & major & Plantain & $1 / 2$ & $X$ & \\
\hline Plantaginaceae & Callitriche & stagnalis (?) & Callitriche des marais & $0 / 1$ & $\mathrm{X}$ & $\mathrm{X}$ \\
\hline Poaceae & Agrostis & capillaris & Agrostide capillaire & $2 / 2$ & $\mathrm{X}$ & $\mathrm{X}$ \\
\hline Polygonaceae & Polygonum & viviparum & Renouée vivipare & $1 / 1$ & $X$ & $X$ \\
\hline Potamogetonaceae & Potamogeton & Crispus (?) & Potamot crépu & $0 / 1$ & $x$ & \\
\hline Ranunculaceae & Ranunculus & sp. & Renoncule & $1 / 1$ & $\mathrm{X}$ & \\
\hline Rosaceae & Alchemilla & sp. & Alchémille & $1 / 1$ & $\mathrm{X}$ & $\mathrm{X}$ \\
\hline Rosaceae & Fragaria & vesca & Fraisier des bois & $1 / 1$ & $X$ & $X$ \\
\hline Rosaceae & Geum & sp. & Benoîte & $1 / 1$ & $\mathrm{X}$ & $\mathrm{X}$ \\
\hline Rosaceae & Rubus & sp. & Ronce & $1 / 1$ & $X$ & $X$ \\
\hline Rosaceae & Rubus & idaeus & Framboisier & $2 / 2$ & $\mathrm{X}$ & $\mathrm{X}$ \\
\hline Rosaceae & Malus & sylvestris (?) & Pommier sauvage & $0 / 2$ & $X$ & $X$ \\
\hline Rosaceae & Sorbus & sp. & Sorbier/alisier & $2 / 2$ & $X$ & $X$ \\
\hline Rosaceae & Spiraea & sp. & Spirée & $0 / 1$ & $X$ & \\
\hline
\end{tabular}

(?) indicates that the species could not be fully identified. District compares the number of samples identified for the taxon (National Botanical Conservatory from the Pyrenees and Midi-Pyrenees, CBNPMP) in the district where it was collected with the total number of collected samples in that district. Study area indicates if the taxon was inventoried at the scale of the study area, according to the CBNPMP. MNHN (National Museum of Natural History) indicates that the taxon was validated by Yves Pauthier (MNHN, Paris). 
no trend regarding light requirements (L-Ellenberg index, $\left.\chi_{(1)}^{2}=0.46, p=0.497\right)$.

\section{Q3 - Dispersal distances}

We summarise in Table 5 the mean and maximal distances covered by male and female brown bears over $18 \mathrm{~h}$. This period of time covers the maximal GRT for bear according to Elfström et al. (2013).

The median GRT (GRT ${ }_{50 \%}$ in Table 2) given for a berrybased diet is roughly $6 \mathrm{~h}$. Bears preferentially feed on berries, especially blueberries (Vaccinium sp.) in summer and early fall (Figure 2). Based on these figures and for the three bears we monitored, the median dispersal distances range between 1.09 and $1.34 \mathrm{~km}$ in summer and a little less in the fall (between 0.85 and $1.15 \mathrm{~km}$, Table 5).

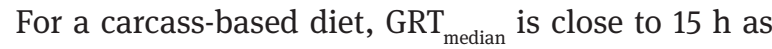
reported in Table 2. Such a diet is more typical of the posthibernation behaviour observed in early spring in the Pyrenees, when bears specifically look for carcasses. At this time of the year, the median dispersal distances were longer and ranged between 2.26 and $2.38 \mathrm{~km}$, except for Hvala (Table 5), a female who stayed much longer in the den because she had cubs. As reported in Table 5, for all seasons, maximum dispersal distances ranged from $3 \mathrm{~km}$ to more than $10 \mathrm{~km}$, depending on the diet (berry-based vs. carcass-based).

\section{Discussion}

Our results globally reflect the current knowledge of brown bear feeding behaviour (Berducou et al. 1983). Although there still remains uncertainty about the timing of defecation of our sampled faeces, ONCFS experts that collected or received the faeces were able to roughly date the freshness of the dung (from 1 to 2 weeks old). Here, we can only report elements concerning the composition of what was consumed but not about the diet selection, since we had no information to assess the precise spatio-temporal distribution of dietary items. The macro-elements we found in the bear faeces support a plant-based diet, consistent with what is generally observed for brown bear in SouthWestern Europe (Naves et al. 2006). The number of plant taxa identified from seeds in the faeces (47 taxa) was quite low (3\%) compared to the number of species available in the local habitat, as recorded by botanical surveys (close to 1500 taxa). Elfström et al. (2014) reported on average 1.9 taxa (228 taxa for 120 faeces samples) per faeces whereas $\mathrm{s}$ 


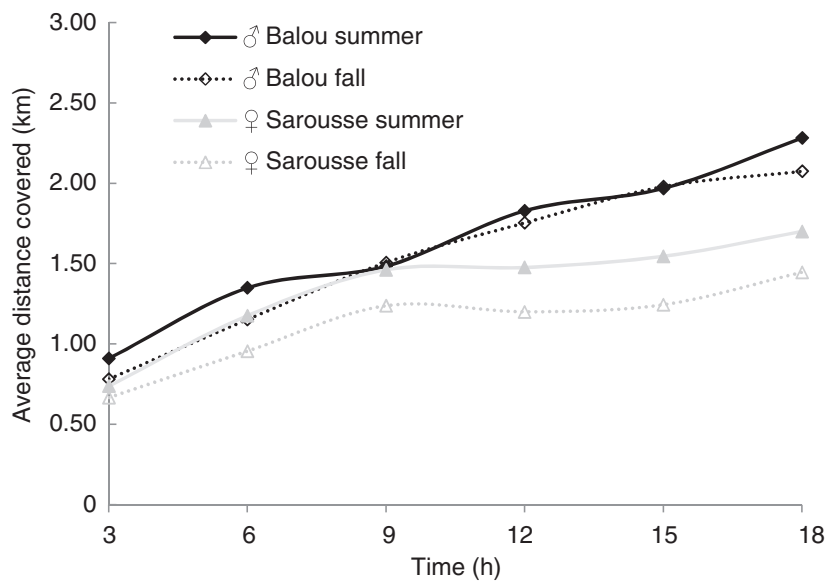

Figure 2: Summer (continuous line) and fall (dashed line) average distance covered by Balou $\widehat{\jmath}$ (black diamonds) and Sarousse $q$ (gray triangles) over an $18 \mathrm{~h}$ period. This time covers gut retention time (GRT) according to Elfström et al. (2013). For a berry-based diet, median $\mathrm{GRT}_{50 \%}$ is $5 \mathrm{~h} 47 \mathrm{~min}$ long and for a carcass-based diet, it is $14 \mathrm{~h} 30 \mathrm{~min}$. Ninety-five percent $\mathrm{Cl}$ have been deleted for better readability but can be found in Table 5 .

we only identified 1.2 taxa ( 47 taxa for 39 faeces samples among which 14 samples did not contain any seeds). This result may be due to the fact that we only identified seeds and not all plant fragments. From a methodological point of view, we acknowledge that metabarcoding is certainly a much more efficient tool than identification under stereomicroscope; however, metabarcoding does not allow distinguishing between seeds and vegetative fragments. Both our small sample size and the small size of the dissected portion of faeces may also explain the reduced number of detected taxa.

In our pilot study, the small number of samples resulted from the fact that we stressed the importance of ensuring independence among defecation events. Hence, we were constrained to mainly use faeces related to our three focal bear individuals and also to cover the total period of activity of bears, even though early spring for instance, especially in mountainous areas is a period of low seed availability. Yet, we can easily imagine that the higher the sample size and the quantity of dung processed the higher the number of seeds and taxa retrieved from the samples. Indeed, a fair number of species that are known to be part of the bear diet in South-Western Europe were absent from our samples. Thus, further work increasing the sample size and focusing on faeces collected during the main seed availability period (summer-fall) will probably increase the number of species detected.

Seeds from fleshy fruits dominated, especially in summer and fall when most of those fruits become available (Willson and Gende 2004). However, seeds from dry fruits were also present in the faeces, though in lower densities, especially during fall and winter. This result is coherent with the brown bear's opportunistic feeding behaviour (Lagalisse 2002). In particular, fruits from forest trees and shrubs represent a major source of energy during the over-eating phase prior to hibernation (Rogers and Applegate 1983). On the other hand, in the spring, seeds are less available in the environment and bears rely on carcasses and the vegetative parts of plants.

Small-sized seeds were generally found intact in the faeces samples while large-sized seeds (e.g. acorns) were rare and usually broken into pieces. Small round seeds with a thick tegument are too small to be damaged by chewing and are known to germinate easily from ruminant excreted faeces (Malo et al. 2000). Hence, like many other large mammals, the bear appears to be a disperser of small-sized seeds.

In our results, the plants dispersed by the brown bears were mostly endozoochorous and epizoochorous, although a total of seven main dispersal modes from a wide range of habitats were represented. Comparing the frequency of endozoochorous species in the faeces to their frequency in the bear habitat revealed that the bears selectively ingested endozoochorous species. For epizoochorous species, the frequency of their seeds in the bear faeces was similar to the plant frequency in bear habitat.

In our study, we did neither monitor the germination of the seeds dispersed nor check for their viability. Traveset and Willson (1997) conclude their study on seed germination of fleshy-fruited shrubs by bears and birds by stating that "the advantages of animal seed dispersal lie more in seed movement away from the parent plant than in seed treatment within the disperser's guts”. Koike et al. (2011) estimated the seed shadow created by Asiatic black bear and did not check for seed germination rate in relation to GRT. Yet, we argue that future research should also focus on the germination rate of the seeds dispersed. Regarding our available germination data, we already have the information that seeds from Vaccinium myrtillus, Vitis vinifera, Hedera helix and probably Sorbus sp. collected from Pyrenean brown bear dung were able to germinate (Brown Bear Network, personal communication).

Median seed dispersal distances varied on average between 0.85 and $1.34 \mathrm{~km}$ in summer and fall, with maximum distances of over $7 \mathrm{~km}$. They suggest smaller movements by Pyrenean brown bears in comparison with those found by other studies. Elfström et al. (2013) reported longer median dispersal distances of berries corresponding to $4 \mathrm{~km}$ and maximal dispersal distances up to $11 \mathrm{~km}$, based on European brown bear movement 
data from Scandinavia, and Patten (1993) reported similar seed dispersal distances (over $3 \mathrm{~km}$ ) with grizzly bears. Individual variability, low sample sizes, differences in topography and habitat composition may all explain the differences observed among cited studies.

In our analysis of bear GPS locations, we were unable to determine the time when individuals were feeding to define the effective starting point of the dispersal events. Like in Koike et al. (2011), we simply estimated dispersal distances as the straight distances between two locations. However, taking into account animal activity and behaviour (Westcott et al. 2005, Russo et al. 2006) would help us better predict effective dispersal distances.

The wild ungulates present in the Pyrenees - red deer (Cervus elaphus), roe deer (Capreolus capreolus), izard (Rupicapra pyrenaica), mouflon (Ovis aries musimon) and wild boar (Sus scrofa) - are known to disperse mostly seeds from open habitats (Heinken et al. 2002) and over shorter distances (unpublished results). Hence, brown bears in the Pyrenees are likely to play a unique complementary role as long-distance seed dispersers of forest plants.

In addition, it is worth noting that in some recent in situ observations, bears consumed the flowers and fruits of Angelica razulii, an Apiaceae forb endemic to the Pyrenees. Applegate et al. (1979) showed that the seeds of Heracleum maximum, a protected North-American forb in the same family as $A$. razulii had an improved germination rate after consumption by grizzly bears. Whether the brown bear in the Pyrenees also plays a crucial role in the dispersal of $A$. razulii, however, needs to be assessed. More generally, there is a need to document the brown bear's role in the dispersal of rare and/or endemic species in Southern Europe.

Acknowledgements: We thank two anonymous reviewers for their comments on the first version that helped us improve the current article. We thank Gérard Largier from the CBNPMP (National Botanical Conservatory from the Pyrenees and Midi-Pyrenees, http://cbnpmp.blogspot.fr/) for the plant lists he provided (database accessed in June, 2013) for each district where faeces had been collected and for the global study area. We also thank Yves Pauthier (MNHN, Paris), in charge of the national reference collection of seeds, for his precious help in identifying the seeds collected. Rachel Barrier provided her personal seed reference collection and Jérôme Sentilles from the Brown Bear Team (ONCFS) in charge of the Brown Bear Network for the central Pyrenees provided the faeces collected in the field and used during that pilot study. The study was funded by the Ministry in charge of Ecology (MEDDE, grant no.
2100858785). We also thank Victoria Moore for proofreading the English article.

\section{References}

Applegate, R.D., L.L. Rogers, D.A. Casteel and J.M. Novak. 1979. Germination of cow parsnip seeds from grizzly bear feces. J. Mammal. 60: 655-655.

Auger, J., S.E. Meyer and H.L. Black. 2002. Are American black bears (Ursus americanus) legitimate seed dispersers for fleshyfruited shrubs? Am. Mid. Nat. 147: 352-367.

Berducou, C., L. Faliu and J. Barrat. 1983. The food habits of the brown bear in the national park of the western Pyrenees (France) as revealed by faeces analysis. Acta Zool. Fenn. 174: 153-156.

Boulanger, V., C. Baltzinger, S. Saïd, P. Ballon, F. Ningre, J.F. Picard and J.L. Dupouey. 2011. Deer-mediated expansion of a rare plant species. Plant Ecol. 212: 307-314.

Cain, M.L., H. Damman and A. Muir. 1998. Seed dispersal and the Holocene migration of woodland herbs. Ecol. Monograph 68: 325-347.

Camarra, J.-J., J. Sentilles, N. Bombillon and P.-Y. Quenette. 2014. Vingt ans de suivi (1993-2012) de la population d'ours brun des Pyrénées: bilan et perspectives. Faune sauvage 302: 31-37.

Cappers, R.T.J., R.M. Bekker and J.E.A. Jans. 2006. Digital seed atlas of the Netherlands. (Barkhuis Publishing: Eelde, The Netherlands).

Clevenger, A.P., F.J. Purroy and M.R. Pelton. 1990. Movement and activity patterns of a European brown bear in the Cantabrian mountains, Spain. In: (Darling, L.M. and Archibald, W.R. eds.) International Conference on Bear Research and Management. Hemlock Printers Ltd. for International Association for Bear Research and Management, Vancouver. 8: 205-211.

Couturier, M. 1954. L'Ours brun. Éditions Arthaud, Grenoble. pp. 905.

Dahle, B. and J.E. Swenson. 2003. Home ranges in adult Scandinavian brown bears (Ursus arctos): effect of mass, sex, reproductive category, population density and habitat type. J. Zool. 260: 329-335.

Elfström, M., O.-G. Støen, A. Zedrosser, I. Warrington and J.E. Swenson. 2013. Gut retention time in captive brown bears Ursus arctos. Wildlife Biol. 19: 317-324.

Elfström, M., M.L. Davey, A. Zedrosser, M. Müller, M. De Barba, O.-G. Støen, C. Miquel, P. Taberlet, K. Hackländer and J.E. Swenson. 2014. Do Scandinavian brown bears approach settlements to obtain high-quality food? Biol. Cons. 178: 128-135.

Ellenberg, H., H.E. Weber, R. Düll, V. Wirth, W. Werner and D. Paulissen. 1991. Zeigerwerte von Pflanzen in Mitteleuropa. Scr. Geobot. 18: 1-258.

Heinken, T., H. Hanspach, D. Raudnitschka and F. Schaumann. 2002. Dispersal of vascular plants by four species of wild mammals in a deciduous forest in NE Germany. Phytocoenologia 32: 627-643.

Howe, F. and J. Smallwood. 1982. Ecology of seed dispersal. Ann. Rev. Ecol. Syst. 13: 201-228.

Huber, D. and H.U. Roth. 1993. Movements of European brown bears in Croatia. Acta Theriol. 38: 151-159. 
Julve, P. 1998. Baseflor. Index botanique, écologique et chorologique de la flore de France. accession date 2013/07/04 (http://perso.wanadoo.fr/philippe.julve/catminat.htm).

Kleyer, M., R.M. Bekker, I.C. Knevel, J.P. Bakker, K. Thompson, M. Sonnenschein, P. Poschlod, J.M. Van Groenendael, L. Klimeš, J. Klimešová, S. Klotz, G.M. Rusch, M. Hermy, D. Adriaens, G. Boedeltje, B. Bossuyt, A. Dannemann, P. Endels, L. Götzenberger, J.G. Hodgson, A.K. Jackel, I. Kühn, D. Kunzmann, W.A. Ozinga, C. Römermann, M. Stadler, J. Schlegelmilch, H.J. Steendam, O. Tackenberg, B. Wilmann, J.H.C. Cornelissen, O. Eriksson, E. Garnier and B. Peco. 2008. The LEDA Traitbase: a database of life-history traits of the Northwest European flora. J. Ecol. 96: 1266-1274.

Koike, S., H. Morimoto, Y. Goto, C. Kozakai and K. Yamazaki. 2008. Frugivory of carnivores and seed dispersal of fleshy fruits in cool-temperate deciduous forests. J. For. Res. 13: 215-222.

Koike, S., T. Masaki, Y. Nemoto, C. Kozakai, K. Yamazaki, S. Kasai, A. Nakajima and K. Kaji. 2011. Estimate of the seed shadow created by the Asiatic black bear Ursus thibetanus and its characteristics as a seed disperser in Japanese cool-temperate forest. Oikos 120: 280-290.

Koike, S., C. Kozakai, Y. Nemoto, T. Masaki, K. Yamazaki, S. Abe, A. Nakajima, Y. Umemura and K. Kaji. 2012. Effect of hard mast production on foraging and sex-specific behavior of the Asiatic black bear (Ursus thibetanus). Mamm. Study 37: 21-28.

Kuhn, K. M. and S.B.V. Wall. 2007. Black bears (Ursus americanus) harvest Jeffrey pine (Pinus jeffreyi) seeds from tree canopies. West. N. Am. Naturalist 67: 384-388.

Lagalisse, Y.A.L. 2002. Etude coproscopique du régime alimentaire d'une population d'Ours bruns (Ursus arctos) réintroduite dans les Pyrénées (1996-1999). Université Paul SabatierToulouse III.

Malo, J.E., B. Jimenez and F. Suarez. 2000. Herbivore dunging and endozoochorous seed deposition in a Mediterranean dehesa. J. Range Manage. 53: 322-328.

Mateo-Sanchez, M.C., S.A. Cushman and S. Saura. 2014. Connecting endangered brown bear subpopulations in the Cantabrian Range (north-western Spain). Anim. Conserv. 17: 430-440.

Mustoni, A., E. Carlini, B. Chiarenzi, S. Chiozzini, E. Lattuada, E. Dupré, P. Genovesi, L. Pedrotti, A. Martinoli, D. Preatoni, L.A. Wauters and G. Tosi. 2003. Planning the brown bear Ursus artos reintroduction in the Adamello Brenta Natural Park. A tool to establish a metapopulation in the central-eastern Alps. Hystrix Ital J Mammol 14: 3-27.
Naves, J., A. Fernandez, C. Rodriguez and M. Delibes. 2006. Brown bear food habits at the border of its range: a long term study. J. Mammal. 5: 899-908.

Patten, L.A. 1993. Seed dispersal patterns generated by brown bears (Ursus arctos) in southeastern Alaska. Washington State University, Pullman, Washington.

Picard, M. and C. Baltzinger. 2012. Hitch-hiking in the wild: should seeds rely on ungulates? Plant Ecol. Evol. 145: 24-30.

Preatoni, D., A. Mustoni, A. Martinoli, E. Carlini, B. Chiarenzi, S. Chiozzini, S. Van Dongen, L.A. Wauters and G. Tosi. 2005. Conservation of brown bear in the Alps: space use and settlement behavior of reintroduced bears. Acta Oecol. 28: 189-197.

Quenette, P.Y., M. Alonso, L. Chayron, P. Cluzel, E. Dubarry, D. Dubreuil, S. Palazon and M. Pomarol. 2001. Preliminary results of the first transplantation of brown bear in the French Pyrenees. Ursus 12: 115-120.

Quenette, P.Y., G. Rauer, D. Hubert, P. Kazensky, F. Knauer, A. Mustoni, S. Palazon and F. Zibordi. 2006. Comparaison du comportement spatial de l'ours brun réintroduits et non réintroduits en Europe. In 'ONCFS Scientific Report' pp. 21-25.

Rogers, L.L. and R.D. Applegate. 1983. Dispersal of Fruit Seeds by Black Bears. J. Mammal. 64: 310-311.

Russo, S.E., S. Portnoy and C.K. Augspurger. 2006. Incorporating animal behavior into seed dispersal models: implications for seed shadows. Ecology 87: 3160-3174.

Saule, M. 1991. La grande flore illustrée des Pyrénées. Éditions Milan, Toulouse. pp. 765.

Taberlet, P., J.J. Camarra, S. Griffin, E. Uhrès, O. Hanotte, L.P. Waits, Dubois-Paganon, C., T. Burke and J. Bouvet. 1997. Noninvasive genetic tracking of the endangered Pyrenean brown bear population. Mol. Ecol. 6: 869-876.

Traveset, A. and M.F. Willson. 1997. Effect of birds and bears on seed germination of fleshy-fruited plants in temperate rainforests of southeast Alaska. Oikos 80: 89-95.

Westcott, D.A., J. Bentrupperbäumer, M.G. Bradford and A. McKeown. 2005. Incorporating patterns of disperser behaviour into models of seed dispersal and its effects on estimated dispersal curves. Oecologia 146: 57-67.

Wiegand, T., J. Naves, T. Stephan and A. Fernandez. 1998. Assessing the risk of extinction for the brown bear (Ursus arctos) in the Cordillera Cantabrica, Spain. Ecol. Monogr. 68: 539-570.

Willson, M. F. and S.M. Gende. 2004. Seed dispersal by Brown Bears, Ursus arctos, in Southeastern Alaska. Can. Field Nat. 118: 499-503. 